remarkable talents, that when he left it for East London (now Queen Mary) College in 1909 he embarked on an honours course in chemistry which he pursued by day while continuing with a correspondence course for an arts degree in the evenings and at week-ends. The resulting B.A. (1911) and B.Sc. (first-class honours, 1912) by the age of twenty foreshadowed the brilliance of his career.

In 1913 Bennett won an exhibition at St. John's College, Cambridge where he read chemistry, physics and mineralogy, twaing a first class in both parts of the Tripos and being elected a Fellow of the College in 1917. He was then working under Prof. W. J. Pope, but his active mind ranged beyond the immediate war-time work, such as that on $\beta \beta^{\prime}$-dichlorodiethyl sulphide, and turned to crystallography, which he had learned under Hutchinson, and stereoisomerism.

Soon after the end of the First World War, Bennett worked for a short time with Strange and Graham, a firm of consulting chemists, and then was appointed a demonstrator at Guy's Hospital, London. From here, in 1924, he went as lecturer to the University of Sheffield, where in 1931 he succeeded Prof. W. Palmer Wynne as Firth professor. After seven years he returned to London to fill the vacancy caused by the retirement of Prof. Samuel Smiles at King's College, London, and soon had to cope with evacuation to Bristol. Here, although his depart. ment suffered from bombing, Bennett kept the teaching going and maintained an output of research.

In 1945, on the death of Sir John Fox, Bennett was appointed Government chemist. To some, this seemed a strange transition, but those who knew his wide knowledge and his mastery of detail were sure that he would justify the appointment-as he did, for the normal tenure was extended, but he did not live to complete the additional two years.

Space permits only a brief mention of a few of the lines along which Bennett worked, but these are selected to show his wide interests : surface tension and the constitution of liquids ; isomerism of some ferrocyanides; reactivity of the chlorine atom in chloro-substituted sulphides; velocities of reactions of various types, particularly with reference to polar effects ; glycols and thioglycols ; stereoisomerism of disulphides, dioxides and related substances ; volency angle of oxygen and of sulphur; crystal form of anhydrous citric acid; configuration of heterocyclic compounds; formation of large-ring sulphur com pounds; liquid crystals ; mechanism of nitration.

Bennett received the degrees of Ph.D. of London and M.A. and Sc.D. of Cambridge. He was elected to the Royal Society in 1947 and was appointed a Companion of the Bath in 1948. He was among the first old students to be made a Fellow of Queen Mary College. He was an honorary secretary of the Chemical Society from 1939 until 1946, having served Chemical Society from 1939 until 1946, having served from 1948 until 1951. He served the Royal Institute of Chemistry on the Council for two years, as examiner for five years, and as vice-president for two years.

In 1918 Bennett married Doris Laycock, a Cambridge graduate, and her tragic death at Christmas 1957 from a rapid form of cancer no doubt aggravated the heart trouble from which he died suddenly and peacefully on February 9, 1959. He combined great gifts with humility and kindliness.

A. D. Mitchell

\section{Dr. H. D. K. Drew}

Harry Dugald Keith Drew died in London at the end of December at the age of seventy-two. He was educated at Queen Elizabeth's School, Barnet, and at Birkbeck College, London, graduating B.Sc. in 1910. His active professional career as a chemist began in 1919 when he joined G. T. Morgan, then professor of chemistry in Birmingham, as research assistant, after war service in the R.N.A.S. In 1922 he was appointed to the teaching staff of the University of Birmingham as lecturer in chemistry; in 1930 he became reader in organic chemistry in the University of London at Queen Mary College, a post which he held until he retired in 1947.

Drew's earliest published work was in collaboration with G. Senter and with A. McKenzie, and was concerned with the investigations on the Walden inversion which were then being carried out at Birkbeck College. In his later work, the interest in stereochemistry was maintained and developed along independent lines. The most striking of these researches was a re-investigation of Vernon's observations on the isomerism of the dialkyl telluronium dihalides, which were assumed to be cis- and transisomers resulting from a planar distribution of the valencies of tellurium. Drew established that the difference between the red $\alpha$-dimethyl telluronium diiodide and the green $\beta$-compound is not one of cis-trans isomerism; the green compound has a soltlike character, $\mathrm{Me}_{3} \mathrm{TeI}, \mathrm{Me}^{\mathrm{T}} \mathrm{I}_{3}$, whereas the red $\alpha$-compound is $\mathrm{Me}_{2} \mathrm{TeI}_{\mathbf{2}}$. He also inferred a tetrahedral distribution of the tellurium valencies. There were other investigations on tellurium and selenium organo-metal compounds, notable among these being the study of the interaction of tellurium tetrachloride with $\beta$-diketones.

In a series of papers from 1930 onwards, some in collaboration with the late Prof. W. Wardlaw and his school, the structure of platinum co-ordination compounds was examined in some detail and many of the inconsistencies and earlier conclusions corrected. Other topics which attracted Drew's interest were chemiluminescence and the metal lakes formed from orthohydroxy azo-compounds. While he was still on the staff in Birmingham, Drew was drawn into work with W. N. Haworth on the investigation of the ring structures of the sugars, and in this both he and E. L. Hirst played an important part in this revision of the then accepted structures.

In the late 1920's, Drew spent a period in Pregl's laboratory in Graz, and he returned enthusiastically in favour of the new system of micro-analysis of carbon compounds. He set up a laboratory for teaching Pregl's methods, and gave regular courses of instruction both in Birmingham and in London to undergraduate and graduate students. $\mathrm{He}$ also set up what was probably the first laboratory for the routine microanalysis of carbon compounds.

Drew was a man of many gifts and interests, among them an active interest in tennis and cricket, yet he never conquered his shyness and reticence to become well known even to his colleagues. The over-riding interest in his life was the practice of chemistry, and to those who had the opportunity of seeing him work at the bench, his skill with small amounts of material and his ability to extract pure crystalline products from the most unpromising material seemed uncanny. He was a man who practised his craft essentially for the satisfaction of accomplishment and not for any personal gain or reward. W. J. HICkINBOTTOM 